\title{
Vulnerability and policy responses in the face of natural resource discoveries and climate change: introduction
}

\author{
John Cockburn ${ }^{1}$, Martin Henseler ${ }^{1}$, Hélène Maisonnave ${ }^{2,1}$ and Luca Tiberti ${ }^{1,3 *}$ \\ ${ }^{1}$ Partnership for Economic Policy (PEP), Nairobi, Kenya \\ ${ }^{2}$ Université du Havre and Partnership for Economic Policy, Le Havre, France and ${ }^{3}$ Laval University, \\ Quebec, Canada \\ *Corresponding author. E-mail: luca.tiberti@ecn.ulaval.ca
}

(Submitted 19 September 2017; accepted 23 June 2018; first published online 30 July 2018)

\begin{abstract}
This special issue contributes to the natural resource economics literature by shining a light on the specific challenges and opportunities faced by developing countries that have recently become dependent on natural resources or are particularly exposed to climate change. It is composed of five studies on countries from all regions of the developing world, involving a variety of natural resources and policy issues. Four of the five studies illustrate how computable general equilibrium models are particularly well-suited, despite their relatively limited past use, to the analysis of natural resources. All five studies are led by researchers based in these countries, providing unique insights into the specific local context. The studies underscore the extreme vulnerability that the introduction of significant natural resource revenues and climate change can create in developing countries. They also show how the choice of appropriate policies to avoid the resource curse varies according to country-specific economic conditions.
\end{abstract}

Keywords: Developing countries; economic growth; natural resources; resource curse

\section{Economic dependency on natural resources}

Economic growth and poverty reduction are crucial policy objectives, particularly in developing countries. When developing countries discover natural resource endowments, their exploitation provides a unique opportunity to pursue these objectives. However, such discoveries can also pose significant risks. Careful management of natural resources and appropriate accompanying policies are essential to avoid potential negative impacts on economic development (i.e., the resource curse) and to ensure that the resulting growth is as inclusive as possible (OECD, 2008).

*The original version of this article listed it incorrectly as a Research Article. It is the Introduction to the Special Issue and has been updated accordingly and a corrigendum published. 
Table 1. Development of economic dependency on natural resource in the economy of world regions and selected developing countries

\begin{tabular}{|c|c|c|c|c|c|c|c|}
\hline & \multicolumn{7}{|c|}{ Percentage share of natural resource rents in GDP } \\
\hline & 1970 & 1980 & 1990 & 2000 & 2005 & 2010 & 2015 \\
\hline \multicolumn{8}{|l|}{ World regions } \\
\hline High income countries & 0.7 & 4.5 & 1.3 & 1.3 & 1.8 & 1.9 & 1.1 \\
\hline East Asia \& Pacific & 1.8 & 19.1 & 8.8 & 3.5 & 5.6 & 6.2 & 1.5 \\
\hline Europe \& Central Asia & 0.7 & 1.4 & 9.6 & 9.9 & 11.0 & 9.3 & 6.2 \\
\hline Latin America \& Caribbean & 1.1 & 8.2 & 4.9 & 3.7 & 6.4 & 5.2 & 2.7 \\
\hline Middle East \& North Africa & 0.4 & 25.3 & 14.4 & 16.7 & 27.4 & 20.6 & 9.5 \\
\hline Sub-Saharan Africa & 4.7 & 19.1 & 14.8 & 13.3 & 16.8 & 14.8 & 8.0 \\
\hline \multicolumn{8}{|l|}{ Case studies } \\
\hline Burkina Faso -Gold & 6.8 & 8.3 & 6.8 & 6.0 & 7.2 & 14.9 & 21.0 \\
\hline Chad-Oil & 4.0 & 10.1 & 7.5 & 10.6 & 38.6 & 24.5 & 13.1 \\
\hline Mongolia-Coal, Copper & ND & ND & 8.7 & 7.9 & 21.6 & 38.6 & 16.5 \\
\hline Niger-Oil, Uranium & 2.2 & 3.4 & 5.4 & 9.1 & 9.6 & 10.1 & 14.8 \\
\hline Guatemala-Water & 1.2 & 2.1 & 1.8 & 1.5 & 1.5 & 2.6 & 2.3 \\
\hline
\end{tabular}

Source: World Bank (2017a).

Note: ND -no data.

The contribution of the rents from natural resources to GDP varies substantially across the various regions of the world (see top half of table 1). In general, such rents are much more important for low income countries, among which the Middle East \& North Africa and Sub-Saharan Africa are the most natural resource-dependent regions.

In the context of this special issue, we focus on a group of countries where mineral resources have only recently emerged as an important sector of the economy: Burkina Faso, Chad, Mongolia and Niger. In Burkina Faso, Chad and Mongolia, natural resource rent shares in GDP increased multifold between 2000 and 2010 (see bottom half of table 1), although falling world commodity prices reduced these shares in Chad (oil) and Mongolia (coal and copper) by 2015 (see figure 1). The progression in Niger (uranium and oil), and continued growth in Burkina Faso (gold), has occurred since 2010, despite falling world prices for oil and gold. To provide a broader overview of the natural resource management issue, we also include Guatemala, which is a country that relies heavily on non-mining natural resources -water and land - agriculture.

Table 1 also illustrates the extreme volatility of natural resource rents. In all world regions, we observe dramatic peaks in rent shares in 1980 and 2005, corresponding to soaring world commodity prices, followed in each case by precipitous declines. Among our case study countries, natural resource rents fell by roughly half between 2010 and 2015 in Chad and Mongolia. This volatility creates uncertainty and vulnerability.

\section{The debates on natural resources in developing economies}

Faced with the growing importance of natural resources in the economy for developing countries and the paradox that well-endowed countries often perform less well 


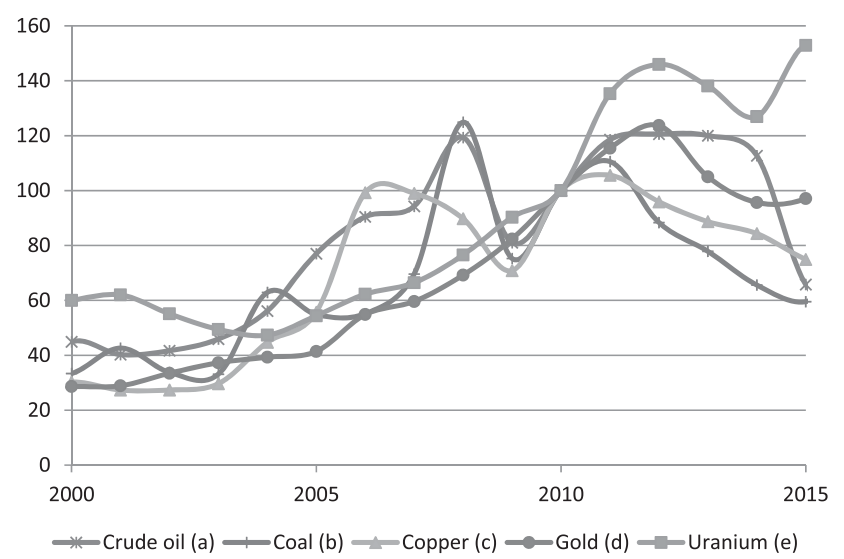

Figure 1. Variation of (real) prices of selected natural resources from 2000 to 2015 (base 100 in the year 2010) Notes: (a) Average price for crude oil. Source: World Bank (2017b). (b) Price for coal from Australia. Source: World Bank (2017b). (c) Price for copper price. Source: World Bank (2017b). (d) Price for gold. Source: World Bank (2017b). (e) Price for natural uranium. Source: ESA (2017).

than non-endowed countries, economists have pursued three channels of reflection (Barbier, 2003): (i) resource depletion and sustainable resource management, (ii) environmental degradation and the environmental Kuznets curve hypothesis, and (iii) the resource curse.

(i) Resource depletion and sustainable resource management

The problems of depletion apply to the exploitation of both renewable and nonrenewable natural resources. The overexploitation of renewable resource stocks (e.g., forestry, fish stocks, water, soil) can lead to irreversible stock depletion. The depletion of non-renewable natural resources (e.g., fossil fuels, minerals) is unavoidable, although technological progress and discoveries can provide access to new resource stocks to prolong the period of exploitation. This said, increased efficiency in exploitation technology may also accelerate wasting (OECD, 2008).

Resource depletion may affect welfare directly in the short term or may only manifest for future generations (Barbier, 2014). Sustainable resource management aims to avoid or limit the negative impacts of depletion. It requires measurement of the rate of depreciation of natural stocks and consideration of the resource-growth nexus in its full complexity (Santopietro, 1998; Rammel et al., 2007; Dauvin and Guerreiro, 2017). This may involve the enforcement of sustainable extraction rates for renewable resources to allow for the regeneration of the stocks (e.g., fish harvesting). For nonrenewable resources, sustainable resource management includes the re-investment of natural resource rents into other sectors, which can compensate for the loss of natural capital by depletion (Hartwick-Solow rule) (Lange and Wright, 2004).

(ii) Environmental degradation and the environmental Kuznets curve hypothesis

The exploitation of natural resources can cause environmental degradation directly through the extraction process of non-renewable resources (e.g., environmental pollution from mining) and through the exploitation of renewable resources (e.g., ecological 
damages from deforestation), and indirectly (e.g., $\mathrm{CO}_{2}$ emissions from the use of fossil fuels). The negative impacts of environmental degradation (e.g., on health and income) usually affect the poor disproportionately to the rich and sometimes even result in displacement or migration (Laczko and Aghazarm, 2009).

The environment Kuznets curve (EKC) hypothesis explains how the environmental degradation depends on the wealth of a country. It describes the relationship between environmental degradation and per capita income as an inverted U-shape (Barbier, 1997, 2003). Many studies find empirical evidence in favour of the EKC hypothesis for different environmental indicators: e.g., for deforestation (Bhattarai and Hammig, 2004), electricity consumption (Burke, 2012), emissions (Cole, 2003; He, 2009; Lipford and Yandle, 2010) and multiple environmental indicators (Cole et al., 1997).

\section{(iii) The resource curse}

The debate surrounding the effects of natural resource exploitation on economic growth (e.g., the resource curse) intersects with the debates on resource depletion (see e.g., Vincent, 1997; Neumayer, 2005) and environmental degradation (see e.g., Burke, 2012; Abou-Ali and Abdelfattah, 2013).

The resource curse describes the paradox that economic growth in many resourcerich developing countries lags behind resource-poor developing countries. Many resource-rich developing countries structure their development around their exploitation. However, they often exploit their resources inefficiently and fail to reinvest natural resource rents in other productive investments (Barbier, 2003). Instead of the expected benefits of windfall revenues from natural resources, the resource curse can provoke negative impacts: reduced economic growth, increased poverty and/or inequality, conflicts and political instability (Siakwah, 2017).

Many studies explore the various causes of the resource curse. The following presentation provides a basic overview drawing on the most recent literature (Badeeb et al., 2017; Dauvin and Guerreiro, 2017; Hailu and Kipgen, 2017; Siakwah, 2017).

(a) The 'Dutch Disease' describes the macro-economic mechanism whereby increased natural resource exports lead to a real currency appreciation that penalizes other tradable sectors. Separate 'spending' and 'pulling' effects are distinguished. The spending of increased natural resource revenues increases wages and non-tradable prices, which cuts profits in other tradable sectors faced with fixed world prices. At the same time, resources are pulled from these other tradable sectors to fuel the natural resource sector. Both effects can result in the contraction of the non-resource tradable sectors and thus hamper long-term economic growth (Badeeb et al., 2017; Dauvin and Guerreiro, 2017).

(b) Vulnerability. On the one hand, volatility in global commodity prices causes pro-cyclical fluctuations in government revenues and export earnings and also reduces investment, especially in countries with poor financial development. Vulnerability can also stem from variability in the availability of renewable resources (e.g., fish stocks) or production factors (e.g., water and sun for agriculture).

(c) Economic mismanagement applies if, in the face of windfall revenues, the government fails to apply appropriate policy measures to counter the resource curse. This includes inappropriate or insufficient investment of resource rents in physical or human capital (e.g., in infrastructure, education) or inappropriate reform of fiscal policies (e.g., increasing tax collection, creating resource-funded fiscal cushions) (Badeeb et al., 2017). 
A recent body of literature focuses on different spending strategies to increase growth and improve welfare through the Bird in Hand theory or the Permanent Income Hypothesis (see e.g., Collier et al., 1997; van der Ploeg, 2011; van der Ploeg and Venables, 2011; Arezki et al., 2012 and Go et al., 2016).

(d) Rent seeking refers to efforts to appropriate natural resource rents by elites who have the capacity to influence policy decisions. The resulting inequalities and poverty can be avoided by redistributive policies that increase the benefits for the poor (Bourguignon, 2012; Badeeb et al., 2017). Pro-poor investments can favour economic growth by increasing the purchasing power of the economy and building human capital (e.g., education, health), which increases labour supply and productivity and can reduce poverty in the long term (see Robichaud et al., 2014; Alter et al., 2017).

(e) Low institutional quality can lead to reduced growth and increased poverty and inequality. Ideally, strong institutions ensure policies to foster economic growth and share benefits with the poor. However, windfall natural resource revenues can undermine the quality of institutions and result in widespread corruption (Badeeb et al., 2017).

The academic literature addresses the resource curse and economic growth in many empirical studies (e.g., Gylfason, 2001; Sachs and Warner, 2001) and in meta analyses and literature reviews (e.g., Havranek et al., 2016; Badeeb et al., 2017; Dauvin and Guerreiro, 2017; Papyrakis, 2017). This literature mainly focuses on countries that began the exploitation of natural resources decades ago. Few studies explore the adaptation of countries to sudden increases in natural resource revenues.

This special issue presents studies on natural resources and economic development for five developing countries - Burkina Faso, Chad, Guatemala, Mongolia and Niger that have recently discovered natural resources or started to face problems in their management. It focuses primarily on the third debate above, i.e., the design of appropriate policies to avoid the resource curse.

\section{The studies in the special issue}

This special issue presents the findings on the relationship between natural resources and economic development for five developing countries. All five studies included here have been led and conducted by teams of researchers from and living in these countries, thus providing unique insights into the issues involved and the nuanced and complex implications, as well as a privileged access to information and knowledge of their local context.

Each case study included in this issue presents a different natural resource, i.e., water in the case of Guatemala, gold for Burkina Faso, uranium and oil in Niger, coal and copper in Mongolia, and oil in the case of Chad. The macro- and micro-economic effects vary according to the type of natural resource and specific characteristics of each country, as they involve, for example, different factor intensities (e.g., agricultural activities are more intensive in unskilled labour than most mining activities) and different degrees of foreign control over the resources in question.

All five studies simulate one or more policy scenarios concerning the management of natural resources. Four of the five studies adopt computable general equilibrium (CGE) models, while the fifth uses an ex-post micro-analytical approach. One of the key contributions of this special issue is to illustrate how CGE models, which are under-represented in the natural resource literature, can constitute an excellent tool to analyse complex macro-micro issues related to natural resource management. The 
authors design scenarios closely based on local, policy-relevant forecasts, legislation and recommendations.

While the papers in this special issue provide a large number of country-specific insights, outlined in the individual papers, two common threads emerge. First, the sudden emergence of natural resource rents and climatic change both create particular issues of overdependence and vulnerability in developing countries. Second, the choice of appropriate policies to avoid the resource curse depends crucially on the specific characteristics of the natural resources and country in question, in ways that allow local researchers to provide particularly robust and unique insights.

\subsection{Vulnerability to global price volatility and climatic change}

In table 1, we observed the significant variations in natural resource rents in all regions of the world due to global commodity price volatility, with peaks in 1980 and 2005 followed by significant declines. If we focus on the key natural resources for our five case studies, we can observe the substantial volatility of global prices since 2000 (see figure 1).

Baatarzorig et al. (2018) study the impacts of global price volatility in Mongolia, which has recently become highly dependent on the mining of copper and coal. Under the assumption that the current copper mining projects (e.g., Oyu Tolgoi project) continue their production until 2020, they simulate a 20 per cent decline in copper prices. Since the economy is largely dependent upon the mining sector, the impacts of the shocks are jarring, with GDP declining by 1.2 per cent and overall employment by 5 per cent. The authors recommend the creation of financial stabilization funds to reduce the country's vulnerability to global price changes.

In Burkina Faso, gold has recently replaced cotton as the country's main export, exposing the country to impacts from volatility in global gold prices. The Burkinabe has responded by reforming the mining tax code. Sisso and Beaumais (2018) simulate a 15 per cent decrease in the price of gold and find that this reduces real GDP by 0.74 per cent, employment by 3 per cent and public revenues by 6 per cent. They show that the landlocked nature of the economy and the poorly-developed financial systems make Burkina Faso particularly vulnerable to shocks in world gold prices.

In the case of agricultural goods, climatic change is an additional source of vulnerability for resource-dependent developing countries. In Guatemala, Vargas et al. (2018) simulate climate change scenarios according to forecasts by CEPAL (2013). Guatemala is characterized by low food security and high vulnerability to the impacts of climate change on the availability of water for agriculture, a key sector of the Guatemalan economy. The forecasted drop in rain water supply negatively affects the productivity of the agricultural sector and, as a consequence, significantly impacts the whole economy, resulting in a decrease in food exports, household income and food security. The study shows that, to ensure economic growth, welfare and food security in the face of volatility in water supply, the instauration of a legal framework to manage water supply is critically urgent. The authors also establish that regional redistribution policies for water can increase welfare and food security, while reducing poverty and inequality.

\subsection{Policy to avoid the resource curse}

Sisso and Beaumais (2018) assess the impacts of the 2014 mining code in Burkina Faso, which increases the taxation of firms in the gold mining sectors. The authors find that the 
policy slightly increases government income ( 0.3 per cent) and spending by 0.42 per cent. However, as the gold sector is only weakly linked to other sectors, the effects on the rest of the economy are negligible. The authors conclude that a more effective policy would be to encourage collaboration between mining companies and domestic industries as part of mining contracts. This policy could promote development of domestic industries, job creation, and an increase in tax revenue from mining.

Niger forecasts an increase in its oil exports through the exploitation of new oil reserves and the development of new transport and refinery capacities. Niger will also start exploiting a new uranium deposit in 2017, and should become the second largest producer in the world. To avoid the resource curse - notably for Niger's important agricultural sector - and to increase economic growth, the government plans to re-invest natural resource rents to address its underdeveloped transport infrastructure. Sangare and Maisonnave (2018) find that this policy would increase long-run production in services ( 0.05 per cent), agriculture ( 0.03 per cent) and the whole economy (real GDP increases by 0.04 per cent). The finding is in line with recent literature showing that infrastructure investments may help avoid the resource curse.

In Chad, rent seeking behaviour by elites and weak institutional quality have hindered rent redistribution policies, although they remain objectives of its Poverty Reduction Strategy and National Development Plan. Gadom et al. (2018) use an ex-post microeconomic impact evaluation analysis to assess the effect of oil revenues on well-being. While revenues from oil exploitation are found to substantially improve multidimensional well-being, an inappropriate and discretionary use of such revenues is likely to further exacerbate existent inequalities in Chad. A few departments, including the capital city and its neighbours, receive a significantly larger share of oil revenues relative to their needs, which translates into a substantially bigger improvement in their wellbeing. In order to avoid the resource curse at the national level, the authors recommend an inclusive governance of natural resources to redistribute oil rents according to local development, socio-demographic and primary infrastructure needs.

Mongolia expects a moderate boom in its coal mining sector in the face of increased demand from China. Historically Mongolia followed a pro-cyclical fiscal policy, which is the expected future policy. Yet this risks exacerbating the effects of the boom and Dutch disease. While Baatarzorig et al. (2018) conclude that Mongolia is less vulnerable to these effects than most other developing countries due to the near absence of other tradable sectors, they find that a countercyclical policy is more appropriate.

\section{Concluding remarks}

This special issue complements the large body of existing literature on the relationship between natural resources, economic growth and social welfare in developing countries. The studies focus on an underanalysed aspect of this literature: countries where natural resources have only recently emerged as key sources of revenues and the specific challenges and opportunities this represent. A variety of natural resources, countries (from all regions of the developing world) and policy issues are analysed using both macro and micro methods of analysis.

The studies show how the sudden emergence of natural resource revenues in a developing country can quickly create problems of dependence and vulnerability to volatility in global prices and climate change. Policy interventions to counteract such problems range from the creation of financial stabilization funds (in Mongolia, copper and coal) to the instauration of a legal framework to manage water supply and the establishment 
of regional redistribution policies for water (in Guatemala, water). They also outline appropriate policies to manage these new-found natural resources to avoid the resource curse, underscoring the importance of adapting to the specific characteristics of the natural resources and country in question. In such a case, the policy interventions proposed in this volume include countercyclical policies (in Mongolia, copper and coal), redistribution of oil rents according to various local development criteria (in Chad, oil), and investment of natural resource rents into transport infrastructure and indication of a collaboration between mining companies and domestic industries as part of mining contracts (in Burkina Faso, gold).

The findings of these studies can practically support the local political decisionmaking processes and the design and evaluation of policies.

This special issue contributes to the literature in a number of ways. It shines a light on the specific issue of the sudden emergence of natural resource rents in a developing country. Four of the five studies adopt a CGE approach and illustrate how this methodology, relatively rare in the natural resource economics literature, is particularly appropriate to the analysis of the complex and economy-wide issues involved. All five studies were led by local researchers, who have a deep and unique perspective on the context of their specific countries.

Acknowledgements. This research work was carried out with financial and scientific support from the Partnership for Economic Policy (PEP) (www.pep-net.org) with funding from the Department for International Development (DFID) of the United Kingdom (or UK Aid), and the Government of Canada through the International Development Research Center (IDRC).

\section{References}

Abou-Ali H and Abdelfattah YM (2013) Integrated paradigm for sustainable development: a panel data study. Economic Modelling 30, 334-342.

Alter A, Ghilardi MF and Hakura DS (2017) Public investment in a developing country facing natural resource depletion. Journal of African Economies 26, 295-321.

Arezki MR, Pattillo MCA, Quintyn MM and Zhu M (2012) Commodity Price Volatility and Inclusive Growth in Low-Income Countries. Washington, DC: International Monetary Fund.

Baatarzorig T, Galindev R and Maisonnave H (2018) Effects of ups and downs of the Mongolian mining sector. Environment and Development Economics 23, doi.org/10.1017/S1355770X18000153.

Badeeb RA, Lean HH and Clark J (2017) The evolution of the natural resource curse thesis: a critical literature survey. Resources Policy 51, 123-134.

Barbier EB (1997) Introduction to the environmental Kuznets curve special issue. Environment and Development Economics 2, 369-381.

Barbier EB (2003) The role of natural resources in economic development. Australian Economic Papers 42, 253-272.

Barbier EB (2014) The challenges for environment and development economics. Environment and Development Economics 19, 287.

Bhattarai M and Hammig M (2004) Governance, economic policy, and the environmental Kuznets curve for natural tropical forests. Environment and Development Economics 9, 367-382.

Bourguignon F (2012) Commodity price volatility, poverty, and growth inclusiveness in sub-Saharan African countries. In Arezki MR, Pattillo MCA, Quintyn MM and Zhu M (eds), Commodity Price Volatility and Inclusive Growth in Low-Income Countries. Washington, DC: International Monetary Fund, pp. 187-224.

Burke PJ (2012) Climbing the electricity ladder generates carbon Kuznets curve downturns. Australian Journal of Agricultural and Resource Economics 56, 260-279.

CEPAL (2013) Impactos Potenciales del Cambio Climático sobre los Granos Básicos en Centroamérica. Sede Subregional de la CEPAL en México, Comisión Económica para América Latina y El Caribe (CEPAL). Available at http://archivo.cepal.org/pdfs/Mexico/2013/M20130042.pdf (in Spanish). 
Cole MA (2003) Development, trade, and the environment: how robust is the environmental Kuznets curve? Environment and Development Economics 8, 557-580.

Cole MA, Rayner AJ and Bates JM (1997) The environmental Kuznets curve: an empirical analysis. Environment and Development Economics 2, 401-416.

Collier P, Ploeg RVD, Spence M and Venables AJ (2010) Managing resource revenues in developing economies. IMF Staff Papers 57, 84-118.

Dauvin M and Guerreiro D (2017) The paradox of plenty: a meta-analysis. World Development 94, 212-231.

ESA (EURATOM Supply Agency) (2017) EURATOM Supply Agency - Annual Report 2016. EURATO Supply Agency (ESA), European Union, 2017. Available at http://ec.europa.eu/euratom/ar/ar2016.pdf.

Gadom GD, Mboutchouang KA and Araar A (2018) The impact of oil revenues on wellbeing in Chad. Environment and Development Economics 23, doi:10.1017/S1355770X18000281.

Go DS, Robinson S and Thierfelder K (2016) Natural resource revenue, spending strategies and economic growth in Niger. Economic Modelling 52, 564-573.

Gylfason T (2001) Natural resources, education, and economic development. European Economic Review 45, 847-859.

Hailu D and Kipgen C (2017) The Extractives Dependence Index (EDI). Resources Policy 51, 251-264.

Havranek T, Horvath R and Zeynalov A (2016) Natural resources and economic growth: a meta-analysis. World Development 88, 134-151.

He J (2009) China's industrial SO2 emissions and its economic determinants: EKC's reduced vs. Structural model and the role of international trade. Environment and Development Economics 14, 227-262.

Laczko F and Aghazarm C (eds) (2009) Migration, Environment and Climate Change: Assessing the Evidence. Geneva: International Organization for Migration.

Lange G-M and Wright M (2004) Sustainable development in mineral economies: the example of Botswana. Environment and Development Economics 9, 485-505.

Lipford JW and Yandle B (2010) Environmental Kuznets curves, carbon emissions, and public choice. Environment and Development Economics 15, 417-438.

Neumayer E (2005) Does high indebtedness increase natural resource exploitation? Environment and Development Economics 10, 127-141.

OECD (Organisation for Economic Co-operation and Development) (2008) Natural Resources and ProPoor Growth: The Economics and Politics. Paris: OECD Publishing.

Papyrakis E (2017) The resource curse - what have we learned from two decades of intensive research? Introduction to the special issue. Journal of Development Studies 53, 175-185.

Rammel C, Stagl S and Wilfing H (2007) Managing complex adaptive systems - a co-evolutionary perspective on natural resource management. Ecological Economics 63, 9-21.

Robichaud V, Tiberti L and Maisonnave H (2014) Impact of increased public education spending on growth and poverty in Uganda. An integrated micro-macro approach. Working Papers MPIA 2014-01, PEP-MPIA.

Sachs JD and Warner AM (2001) The curse of natural resources. European Economic Review 45, 827-838.

Sangare $\mathbf{S}$ and Maisonnave $\mathbf{H}$ (2018) Mining and petroleum boom and public spending policies in Niger: a dynamic computable general equilibrium analysis. Environment and Development Economics 23, doi.org/10.1017/S1355770X18000104.

Santopietro GD (1998) Alternative methods for estimating resource rent and depletion cost: the case of Argentina's YPF. Resources Policy 24, 39-48.

Siakwah P (2017) Are natural resource windfalls a blessing or a curse in democratic settings? Globalised assemblages and the problematic impacts of oil on Ghana's development. Resources Policy 52, 122-133.

Sisso DC and Beaumais O (2018) Gold price volatility, tax receipts and employment: can Burkina Faso's adaptation strategy avoid the resource curse? Environment and Development Economics 23, doi.org/10.1017/S1355770X18000037.

van der Ploeg F (2011) Natural resources: curse or blessing? Journal of Economic Literature 49, 366-420.

van der Ploeg F and Venables AJ (2011) Harnessing windfall revenues: optimal policies for resource-rich developing economies. The Economic Journal 121, 1-30.

Vargas R, Cabrera M, Cicowiez M, Escobar P, Hernández V, Cabrera J and Guzmán V (2018) Climate risk and food availability in Guatemala. Environment and Development Economics 23, [insert DOI]. 
Vincent JR (1997) Resource depletion and economic sustainability in Malaysia. Environment and Development Economics 2, 19-37.

World Bank (2017a) Total natural resources rents (\% of GDP). World Bank data. Available at http://data.worldbank.org/indicator/NY.GDP.TOTL.RT.ZS.

World Bank (2017b) World Bank Commodity Price Data (The Pink Sheet) - Annual Prices (Real). Commodity Markets - Annual Prices August 2017. Available at http://www.worldbank.org/en/research/ commodity-markets.

Cite this article: Cockburn J, Henseler M, Maisonnave H, Tiberti L (2018). Vulnerability and policy responses in the face of natural resource discoveries and climate change: introduction. Environment and Development Economics 23, 517-526. https://doi.org/10.1017/S1355770X18000347 